\title{
Effect of the enteroinsular axis on both the A- and B-cell response to arginine after oral glucose in man
}

\author{
I. Shimizu, M. Hirota, C.Ohboshi, A. Mizuno and K. Shima \\ Department of Laboratory Medicine, Tokushima University Medical School, Tokushima, Japan
}

\begin{abstract}
Summary. Studies were made on the effect of the enteroinsular axis on amino acid-induced insulin and glucagon secretion during hyperglycaemia in man. The responses of plasma immunoreactive insulin, C-peptide, and immunoreactive glucagon to arginine infusion were investigated in nine healthy subjects after induction of hyperglycaemia by an oral glucose load and by intravenous glucose infusion to produce similar glucose concentrations in the arterialised blood. The plasma immunoreactive insulin and C-peptide levels increased to higher levels after an oral glucose load than after an intravenous infusion of glucose. The incremental areas under the immunoreactive insulin and C-peptide curves during arginine infusion were significantly greater $(p<0.01)$ after oral than after intravenous glucose administration. The plasma
\end{abstract}

immunoreactive glucagon level was suppressed equally after oral and intravenous glucose loads. However, during subsequent arginine infusion, the plasma immunoreactive glucagon level rose more in the presence of hyperglycaemia induced by oral than intravenous glucose. The incremental area under the plasma immunoreactive glucagon curve during arginine infusion was 1.6-fold greater after glucose ingestion than after intravenous glucose infusion. These results suggest that the enteroinsular axis has a stimulatory effect on the responses of pancreatic A and B cells to arginine after oral glucose administration.

Key words: Enteroinsular axis, insulin, glucagon, arginine, arterial blood glucose.
The peripheral insulin concentration is known to be higher after an oral or jejunal load than after an intravenous (i.v.) load of glucose [1,2]. This difference has been suggested to be due to secretion of "incretin" from the upper gastrointestinal tract during oral glucose absorption. Incretin in the original sense refers only to an endocrine transmitter(s) for insulin release; i. e. to a part of the complex neuro-endocrine system called the "enteroinsular axis", which includes all the stimuli from the gut to different cell types of the pancreatic islets [3].

Arginine ingestion has also been known to be insulinotropic since Dupré and colleagues demonstrated that intraduodenal infusion of arginine caused a sustained increase in serum insulin levels which could not be accounted for by the effects of circulating amino acid and glucose [4]. Moreover, Unger et al. have reported both enhanced insulin and glucagon responses after intraduodenal as opposed to i.v. arginine administration in dogs [5]. While there is marked synergism between the effects of glucose and amino acids on insulin release both in vivo [6,7] and in vitro [8], it is unclear how putative incretin secreted from the upper gastroin- testinal tract during oral glucose-absorption influences amino acids-induced insulin and glucagon responses. Since humans are omnivorous, an interesting problem is whether the enteroinsular axis affects pancreatic Aand B-cell function stimulated by amino acids in the presence of hyperglycaemia.

To obtain information on this problem, we measured the responses of glucagon and insulin to arginine infusion in healthy subjects after induction of hyperglycaemia by oral and i.v. glucose loads. The amount of glucose infused was adjusted to produce the same increase in the arterialised blood glucose level as that after the oral glucose load [9].

\section{Subjects and methods}

\section{Subjects}

Nine normal subjects (eight men and one woman) were studied. The mean age was $24 \pm 4$ years with a range of 19 to 51 years. The mean body mass index was $23.3 \pm 0.6 \mathrm{~kg} / \mathrm{m}^{2}$. None of the subjects had a family history of diabetes and they all gave normal results in an oral glucose tolerance test [10]. All the subjects received a diet containing 
at least $200 \mathrm{~g}$ carbohydrate per day with adequate food energy for 3 days prior to testing. Before the study, they were told about the nature and effects of the tests and gave their consent to participate.

\section{Protocol}

All tests were performed in the morning after an overnight fast. An antecubital i.v. polyethylene catheter was inserted in each arm, one for collection of venous blood and the other for infusion of arginine with or without glucose. A third polyethylene catheter was inserted retrogradely into a dorsal vein of the hand, which was enclosed in a warming chamber throughout the study. For collection of arterialised blood, as a substitute for arterial blood $[9,11]$, each preheated period of at least $2 \mathrm{~min}$ was used to allow blood flow in the hand to adjust to the increased temperature (air at $55^{\circ} \mathrm{C}$ ). Glucose infusions and blood sampling for analyses were performed on contralateral arms.

Normoglycaemic studies. Arginine $\mathrm{HCl}(30 \mathrm{~g})$, dissolved in $300 \mathrm{ml}$ sterile water, was infused at constant flow rate for $30 \mathrm{~min}$. Blood samples were collected at $-10,0,10,20,30,45,60$, and 90 min during the test.

Hyperglycaemic studies. In the first test, the subjects received $100 \mathrm{~g}$ of glucose orally in the form of a commercially available test solution (Trelan-G50, Shimizu Pharmaceutical Co., Shizuoka, Japan), and $60 \mathrm{~min}$ later an infusion of $30 \mathrm{~g}$ arginine over $30 \mathrm{~min}$. Venous and arterialised blood samples were collected at $-10,0,5,10,20,30,40$, $50,60,70,80,90,105,120,150$, and 180 min during the test. Additional samples of arterialised blood were taken at 5-min intervals during the test to obtain data on glucose concentrations for matching with those during the second test.

In the second test (14-21 days after the first), i.v. infusion of glucose (as a sterile $25 \%$ solution in water) was started 60 min before arginine infusion. The i.v. infusion was designed to give the same glucose concentration profile as that after oral glucose ingestion. Accuracy was assured by repeated measurements of the arterialised blood glucose level by a reflectance meter (Glucometer II, MilesSankyo Co., Tokyo, Japan). Since data on the glucose concentration could be obtained within $50 \mathrm{~s}$ of blood sampling, the infusion rate could be adjusted for deviations from the profile obtained during the first test with oral glucose. Data on the glucose load obtained by the use of the Glucometer II corresponded to values obtained by the glucose oxidase method ( $r=0.95$ ).

Plasma glucose concentrations were measured in arterialised blood samples; plasma immunoreactive insulin (IRI), C-peptide, and immunoreactive glucagon (IRG) were determined in venous blood samples.

\section{Assays}

Arterialised blood glucose concentrations were measured by an enzymatic glucose oxidase method. Plasma IRI and C-peptide concentrations were measured by double antibody techniques using commercial kits (Daiichi Radioisotope, Tokyo, Japan; Shionogi Pharmaceutical Co., Osaka, Japan, respectively). The lower limits of detection for the IRI and C-peptide assay systems were $3 \mathrm{mU} / \mathrm{l}$ and $0.2 \mu \mathrm{g} / 1$ respectively.

Plasma IRG was determined radioimmunologically using antibody against the 19-29 C-terminal fragment of glucagon, OAL 123 [12]. Antiserum OAL 123 showed low cross reactivity with porcine glicentin, which was only $2 \%$ that of glucagon, and no cross reactivity with several glucagon fragments tested, such as glucagon (1-12), (1-17), (13-17), (14-22), (23-25), and (26-29) [12]. The standard diluent used for the assay was phosphate buffer $(10 \mathrm{mmol} / 1, \mathrm{pH} 7.4)$ containing, per liter, $5 \mathrm{~g}$ of bovine serum albumin, $25 \mathrm{mmol}$ of EDTA, $140 \mathrm{mmol} \mathrm{NaCl}$ and $200 \mathrm{mg}$ of sodium azide. Mixed in each incubation tube were $100 \mu \mathrm{ll}$ of diluted antiserum (OAL 123 diluted, 60,000 -fold), $100 \mu \mathrm{l}(\approx 10,000 \mathrm{cpm})$ of labelled glucagon, $100 \mu \mathrm{l}$ of glucagon standard or unknown sample, and $400 \mu \mathrm{l}$ of standard diluent containing $1000 \mathrm{KIU}$ aprotinin. The mixture was incubated for $48 \mathrm{~h}$ at $4^{\circ} \mathrm{C}$. The antibody bound antigen was precipitated by incu-
Table 1. Effect of arginine infusion on incremental areas under the curves of plasma IRI, C-peptide and IRG under normoglycaemic condition in nine normal subjects. Experimental conditions are described in Figure 1

\begin{tabular}{llll}
$\begin{array}{l}\sum \Delta \text { Glucose } \\
(\mathrm{mmol} \cdot\end{array}$ & $\begin{array}{l}\sum \Delta \mathrm{IRI} \\
(\mathrm{mU} \cdot\end{array}$ & $\begin{array}{l}\sum \Delta \mathrm{C} \text {-peptide } \\
(\mu \mathrm{g} \cdot\end{array}$ & $\begin{array}{l}\sum \Delta \mathrm{IRG} \\
\mathrm{mg} \cdot \\
\left.\mathrm{min}^{-1} \cdot 1^{-1}\right)\end{array}$ \\
\hline $3.13 \pm 0.71$ & $95.6 \pm 11.3$ & $10.59 \pm 1.89$ & $439.8 \pm 56.3$ \\
\hline
\end{tabular}

Values are means $\pm S E M$

Table 2. Effect of arginine infusion on incremental areas under the curves of plasma IRI, C-peptide and IRG after oral and i.v. glucose loads in nine normal subjects. Experimental conditions are described in Figure 2

\begin{tabular}{lllll}
\hline $\begin{array}{l}\text { Glucose } \\
\text { load }\end{array}$ & $\begin{array}{l}\sum \Delta \text { Glucose } \\
\mathrm{mmol} \cdot \\
\mathrm{min}^{-1} \cdot 1^{-1}\end{array}$ & $\begin{array}{l}\sum \Delta \text { IRI } \\
\mathrm{mU} . \\
\mathrm{min}^{-1} \cdot 1^{-1}\end{array}$ & $\begin{array}{l}\sum \Delta \mathrm{C}-\text { peptide } \\
\mu \mathrm{g} \cdot \\
\mathrm{min}^{-1} \cdot 1^{-1}\end{array}$ & $\begin{array}{l}\sum \Delta \mathrm{IRG} \\
\mathrm{ng} \cdot \\
\mathrm{min}^{-1} \cdot 1^{-1}\end{array}$ \\
\hline Oral & $-3.16 \pm 1.00$ & $238.9 \pm 47.6^{\mathrm{a}}$ & $24.83 \pm 3.29^{\mathrm{a}}$ & $646.2 \pm 75.1^{\mathrm{a}}$ \\
i.v. & $-4.87 \pm 1.65$ & $131.1 \pm 25.4$ & $13.89 \pm 2.47$ & $393.6 \pm 49.0$ \\
\hline
\end{tabular}

Values are means \pm SEM. ${ }^{\mathrm{a}}$ Indicates significant differences $(p<0.01)$ between values after glucose administration by the two routes

bation with goat anti-rabbit $\gamma$-globulin serum (diluted $1: 10$ ) and normal rabbit serum (diluted $1: 100$ ) for $24 \mathrm{~h}$ at $4^{\circ} \mathrm{C}$. The supernatant was decanted, and the radioactivity of the pellet was counted. The minimum detection limit of this assay system was $20 \mathrm{ng} / 1$. Interassay variation was 4.8 to $8.1 \%$ [13].

\section{Statistical analysis}

$\sum \Delta$ values are expressed as the incremental areas for $30 \mathrm{~min}$ during arginine infusion, i.e. the areas enclosed by the response curves above the concentrations at the start of infusion.

The Wilcoxon matched pairs signed rank test was used for all statistical analyses. Data are presented as means \pm SEM and a $p$ value of less than 0.05 was regarded as significant.

\section{Results}

\section{Normoglycaemic studies}

In normoglycaemic studies, arginine infusion induced the expected significant $(p<0.05)$ rise in plasma IRI, $C$-peptide and IRG concentrations; similarly the arterialised blood glucose levels increased, although without statistical significance (Fig.1). Table 1 shows the incremental areas for the arterialised blood glucose, plasma IRI, C-peptide and IRG concentrations determined over $30 \mathrm{~min}$ after arginine infusion.

\section{Hyperglycaemic studies}

The mean arterialised blood glucose concentrations in response to oral and i.v. glucose loads with subsequent arginine infusions are shown in Figure 2. The arterialised blood glucose concentrations in the oral and i.v. tests were not significantly different. 


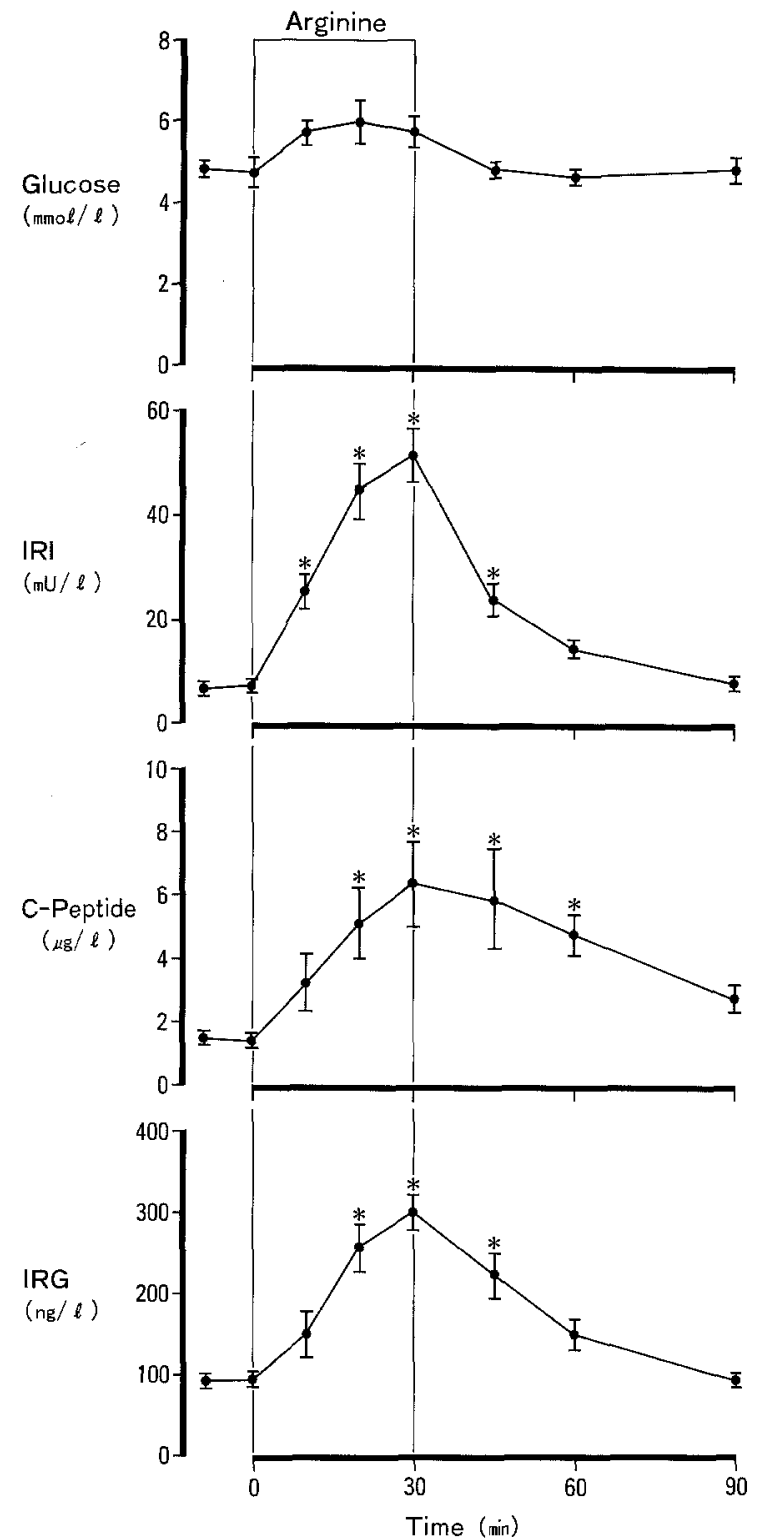

Fig.1. Effect of arginine infusion on plasma hormone levels in venous blood and glucose levels in arterialised blood under normoglycaemic conditions in nine normal subjects. Plasma immunoreactive insulin (IRI), C-peptide, immunoreactive glucagon (IRG) and arterialised blood glucose concentrations were measured as described under "Subjects and methods". Values are means \pm SEM. Asterisks indicate significant differences $(p<0.05)$ from the value at the start of infusion in the same group

The plasma IRI levels (Fig. 2) rose more after an oral than i.v. glucose load, reaching maxima of $69.3 \pm$ 9.9 and $22.9 \pm 3.1 \mathrm{mU} / 1$, respectively, $30 \mathrm{~min}$ after glucose loading. When arginine was given, the levels increased further to peaks of $147.1 \pm 26.4$ and $64.7 \pm$ $8.3 \mathrm{mU} / 1$, respectively, $20 \mathrm{~min}$ after commencement of arginine infusion. The incremental area under the plasma IRI curve during arginine infusion $\left(\sum \Delta\right.$ IRI) was 1.8-fold more after oral glucose than after i.v. glucose loading (Table 2).

Like the IRI level, the plasma C-peptide level (Fig. 2) increased more after oral than i.v. glucose load-

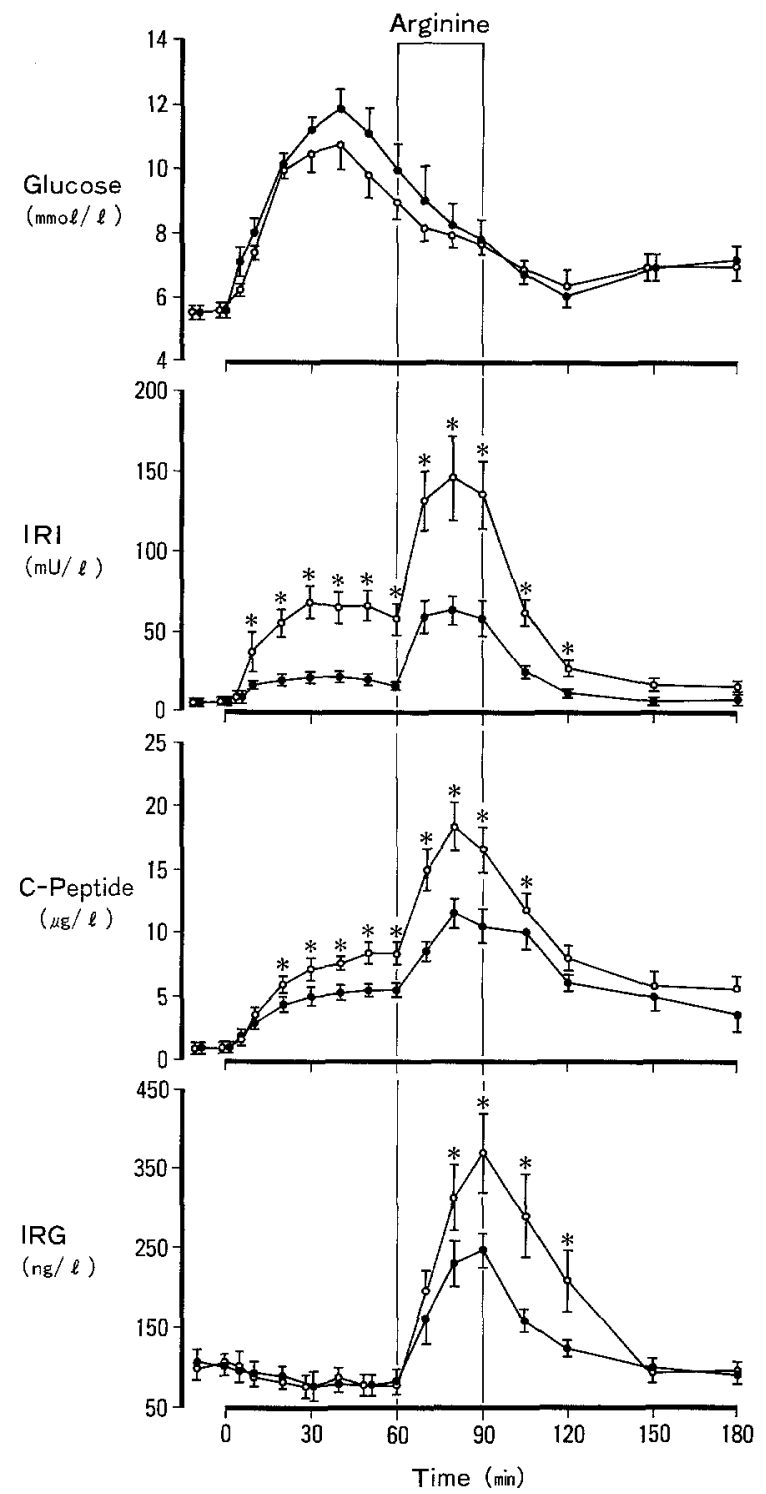

Fig. 2. Responses of plasma hormone levels in venous blood and glucose levels in arterialised blood to arginine infusion after oral glucose administration $(0)$ and isoglycaemic i.v. glucose infusion $(\bullet)$ in nine normal subjects. Experimental conditions are described under "Subjects and methods". Values are means \pm SEM. Asterisks indicate significant differences $(p<0.01)$ between values after glucose administration by the two routes

ing, and during subsequent arginine infusion the peak levels attained were $18.44 \pm 1.94$ and $11.66 \pm 1.10 \mu \mathrm{g} / \mathrm{l}$, respectively, the former being significantly higher $(p<0.01)$ than the latter. The $\sum \Delta \mathrm{C}$-peptide in response to the arginine infusion was 1.8 -fold more after oral glucose than i.v. glucose loading (Table 2).

The plasma IRG levels (Fig. 2) were suppressed equally after oral and i.v. glucose loads, the responses not being significantly different during the 60 -min period before arginine infusion. However, with the start of arginine infusion at $60 \mathrm{~min}$, the IRG levels rose more after oral than i.v. glucose loading, reaching peak lev- 
els at $90 \mathrm{~min}(373.7 \pm 48.5$ and $250.1 \pm 20.6 \mathrm{ng} / 1$ for oral and i.v. loads, respectively) under blood glucose levels elevated to similar extents. The $\sum \Delta$ IRG during arginine infusion was 1.6 -fold more after glucose ingestion than after i.v. glucose infusion (Table 2).

\section{Discussion}

In the present study we found that the increases in the plasma IRI and IRG levels in response to arginine were significantly greater $(p<0.05)$ after oral glucose administration than after isoglycaemic $i . v$. glucose infusion. The results show that the enteroinsular axis affects pancreatic A-cell as well as B-cell functions.

Gibby and Hales [14] have recently questioned the hypothesis of the enteroinsular axis since they observed that the greater plasma insulin response to hyperglycaemia after an oral glucose load than after an i.v. glucose load was not accompanied by a comparable increase in plasma C-peptide. However, they adjusted the dose of i.v. glucose to match the glucose concentration produced by oral glucose in venous blood, not arterial blood. Since it is the glucose level in arterial blood that regulates insulin and C-peptide secretion by pancreatic B cells, in this work we matched the glucose concentrations in arterialised rather than venous blood, and demonstrated similar increases in the peripheral plasma $\mathrm{C}$-peptide concentration and in the insulin level after i.v. and oral glucose loads. These results are in accordance with those in a recent report [9].

Using a sequential infusion method, Levin et al. observed that prior infusion of glucose enhanced the effect of arginine on insulin release but that no other combinations of separate infusions of glucose and arginine resulted in enhancement of insulin secretion, suggesting that an increase in blood glucose level may play a role in the insulin response to subsequent arginine infusion [7]. These results are compatible with the present findings that the incremental areas for the plasma IRI and C-peptide concentrations determined during arginine infusion showed an increase from 95.6 to $131.1 \mathrm{mU} \cdot \mathrm{min}^{-1} \cdot 1^{-1}$ and from 10.69 to $13.89 \mu \mathrm{g}$. $\min ^{-1} \cdot 1^{-1}$, respectively, in the hyperglycaemic as opposed to normoglycaemic state. In the present study, however, the magnitudes of increases in plasma IRI and C-peptide caused by arginine differed depending on how hyperglycaemia was induced; i.e., it was significantly greater $(p<0.01)$ after oral than isoglycaemic i.v. glucose administration (Table 2). Although a typical dietary intake of arginine would be approximately 3 -fold lower than the $30 \mathrm{~g}$ arginine used in the present study, these results suggest that the pancreatic B-cell response to arginine was augmented as much by gastrointestinal factors as by hyperglycaemia. If so, the enteroinsular axis may affect the pancreatic B-cell responses to other insulinogenic substances besides glucose.
In the present study, the increase in plasma IRG levels by arginine infusion after i.v. glucose load tended to be less than the levels under the normoglycaemic condition. The suppression that we have observed is most likely due to the inhibitory consequences of hyperglycaemia. However, the incremental area in the IRG concentrations in response to arginine was significantly greater $(p<0.05)$ under hyperglycaemic conditions induced by oral glucose than under normoglycaemic conditions. These findings suggest that arginine infused after an oral glucose load overrode the suppressive effect of hyperglycaemia in respect of IRG secretion. It seems unlikely that the enhanced glucagon response to arginine after oral glucose is a consequence of impaired clearance of glucagon, judging from the data reported by Ishida et al. [15] that fractional hepatic extraction of glucagon was unchanged after oral glucose administration in conscious dogs, although our species are different from theirs.

Of the chemically defined gastrointestinal hormones, gastric inhibitory polypeptide (GIP) and glucagon-like peptide (GLP)-I(7-37) are the main incretin candidates $[3,16]$. Recent work suggests that there is a comparable increase in insulin secretion with GLPI(7-37) at concentrations 100 -fold lower than those required for an insulinotropic response to GIP [16]. However, any definite glucagonotropic activity of GLP-I (7-37) in humans remains to be elucidated.

What is the physiological significance of the augmented glucagon and insulin secretion stimulated by arginine in the presence of hyperglycaemia produced by oral glucose? Insulin and glucagon are the main hormones regulating glucose homeostasis, and generally have antagonistic effects on glycogenolysis. However, their combined effects on hepatic amino acid transport are not antagonistic: when added together to isolated hepatocytes [17] or cultured hepatocytes [18], their stimulatory effect on hepatic amino acid transport were approximately additive.

Judging from the present data together with those reported by Unger et al. [5], Szecówka et al. [19], and Pederson and Brown [20], the enteroinsular axis is operative on both A and B cells. Moreover, the insulin and glucagon secreted simultaneously by the pancreatic A and B cells, respectively, in response to arginine after an oral glucose load may play some role in hepatic amino acid transport.

Acknowledgment. This work was supported in part by a Grant-in-Aid for Scientific Research No.59480254 from the Ministry of Education, Science and Culture of Japan.

\section{References}

1. McIntyre N, Holdsworth CD, Turner OS (1964) New interpretation of oral glucose tolerance. Lancet II: $20-21$

2. Brown JC, Otte SC (1978) Gastrointestinal hormones and the control of insulin secretion. Diabetes 27: 782-789 
3. Creutzfeldt W (1979) The incretin concept today. Diabetologia 16: $75-85$

4. Dupré J, Curtis JD, Waddell RW, Beck JC (1968) Alimentary factors in the endocrine response to administration of arginine in man. Lancet II: $28-30$

5. Unger RH, Ohneda A, Valverde I, Eisentraut AM (1967) Mechanisms of response of plasma "glucagons" to ingested nutrients: evidence for enteric control of islet hormone secretion. J Clin Invest 46: 1125-1126

6. Efendic S, Cerasi E, Luft R (1971) Role of glucose in arginine-induced insulin release in man. Metabolism 20: 568-579

7. Levin SR, Karam JH, Hane S, Grodsky GM, Forsham PH (1971) Enhancement of arginine-induced insulin secretion in man by prior administration of glucose. Diabetes 20: 171-176

8. Milner RDG (1970) The stimulation of insulin release by essential amino acids from rabbit pancreas in vitro. $J$ Endocrinol 47: 347-356

9. Hampton SM, Morgan LM, Tredger JA, Cramb R, Marks V (1986) Insulin and C-peptide levels after oral and intravenous glucose: contribution of enteroinsular axis to insulin secretion. Diabetes 35: 612-616

10. Andres R (1971) Aging and diabetes. Med Clin N Am 55: 835-846

11. Jackson RA, Blix PM, Matthews JW, Morgan LM, Rubenstein AH, Nabarro JDN (1983) Comparison of peripheral glucose uptake after oral glucose loading and a mixed meal. Metabolism 32: 706-710

12. Nishino $T$, Kodaira $T$, Shin $S$, Imagawa $K$, Shima $K$, Kumahara Y, Yanaihara C, Yanaihara N (1981) Glucagon radioimmunoassay with use of antiserum to glucagon C-terminal fragment. Clin Chem 27: 1690-1697

13. Shima K, Sawazaki N, Tanaka R, Tarui S, Nishikawa M (1975) Effect of exposure to chloramine-T on the immunoreactivity of glucagon. Endocrinology 96: 1254-1260
14. Gibby OM, Hales CN (1983) Oral glucose decreases hepatic extraction of insulin. Br Med J 286: 921-923

15. Ishida T, Chap Z, Chou J, Lewis R, Hartley C, Entman M, Field JB (1983) Differential effects of oral, peripheral intravenous, and intraportal glucose on hepatic glucose uptake and insulin and glucagon extraction in conscious dogs. J Clin Invest 72: $590-601$

16. Mojsov S, Weir GC, Habener JF (1987) Insulinotropin: glucagon-like peptide I(7-37) co-encoded in the glucagon gene is a potent stimulator of insulin release in the perfused rat pancreas. $\mathrm{J}$ Clin Invest 79: 616-619

17. Fehlmann M, Le Cam A, Freychet P (1979) Insulin and glucagon stimulation of amino acid transport in isolated rat hepatocytes: synthesis of a high affinity component. J Biol Chem 254: 10431-10437

18. Kelly DS, Shull JD, Potter VR (1980) Hormonal regulation of amino acid transport and cAMP production in monolayer cultures of rat hepatocytes. J Cell Physiol 103: 159-168

19. Szecówka J, Lins PE, Efendić S (1982) Effects of cholecystokinin, gastric inhibitory polypeptide, and secretin on insulin and glucagon secretion in rats. Endocrinology 110: 1268-1272

20. Pederson RA, Brown JC (1978) Interaction of gastric inhibitory polypeptide, glucose and arginine on insulin and glucagon secretion from the perfused rat pancreas. Endocrinology 103: 610-615

Received: 18 May 1987

and in revised form: 24 September 1987

Dr. Ichiro Shimizu

Department of Laboratory Medicine

Tokushima University Medical School

Kuramoto-cho, Tokushima 770

Japan 